\title{
EDITORIAL
}

\section{Repeated low dose allergen exposure: a new investigational model of asthma as a persistent disease?}

\author{
P.J. Sterk
}

Asthma is a persistent disease, characterized by episodic chest symptoms and variable airways obstruction [1]. Its pathogenesis is determined both by genetic factors $[2,3]$ and by environmental exposures among which allergens $[4,5]$ and respiratory virus infections $[6,7]$ seem to predominate.

The pathology of asthma is characterized by features of acute and chronic airways inflammation, such as epithelial desquamation, leucocyte infiltration, mucosal and adventitial swelling, smooth muscle hyperplasia or hypertrophy, and subepithelial collagen deposition [8]. There is increasing evidence that the eosinophilic infiltrate [9] and the expression of the cytokines interleukin (IL)-4 and IL-5 [10] within bronchial biopsy specimens are associated with the clinical characteristics of asthma.

\section{Human investigational models of asthma}

The acute inflammatory events in patients with asthma have largely been unravelled by using challenges with proinflammatory stimuli, such as (single-dose) allergen provocation [11, 12] or experimental virus infection [13, 14]. However, such models are almost invariably based on acute flare-ups of airways inflammation, whereas the development and consequences of its chronicity still remain to be resolved [15]. The latter seems to be of vital importance since:

1) chronic features of inflammation, such as structural remodelling due, for example, to subepithelial fibrosis [16], smooth muscle growth [17], increased vascularity [18], and airway wall thickening (as measured by high resolution computed tomography (HR-CT) scan [19] or by histology [20]), appear to be major determinants of the severity of airways obstruction in asthma [21].

2) chronic exposure to allergens might "prime" the response to acutely encountered pro-inflammatory stimuli, thereby potentially facilitating asthma exacerbations due to subsequent high dose allergen exposure [22] or respiratory virus infections [23, 24].

Hence, understanding the chronicity of airways inflammation will be essential for developing new and specific therapeutic targets for asthma, particularly those with more sustained activity than the ones currently available.

Correspondence: P.J. Sterk, Lung Function Laboratory, C2-p, Leiden University Medical Centre, P.O. Box 9600, NL-2300 RC Leiden, The Netherlands. Fax: 31715154691.

\section{Repeated low-dose allergen exposure}

Apart from descriptive studies in moderate-to-severe asthma, the chronicity of airways inflammation can be investigated experimentally by repeated, low-dose allergen inhalation. Such controlled laboratory conditions mimic the patient's natural exposure to environmental allergens. The first study in asthmatics using repeated sub-bronchoconstrictive doses of allergen has been shown to induce airway hyperresponsiveness to histamine [25].

In the present issue of the Journal, SuLAKVELIDZE et al. [26] present the clinical, physiological and cellular consequences of repeated low-dose allergen exposure in patients with asthma. Allergen or its diluent were inhaled on five subsequent days, the allergen dose being chosen such that it caused about a 5\% fall in forced expiratory volume in one second (FEV1) only. The results show that in the absence of meaningful bronchoconstriction to the allergen exposure, the patients developed night-time symptoms and increased their $\beta_{2}$-agonist usage. In addition, during these exposure days there was a steady worsening of hyperresponsiveness to methacholine, associated with increases in induced sputum of: eosinophils; EG2+ stained eosinophils; metachromatic cells; eosinophil cationic protein (ECP); and IL-5 levels [26]. This indicates that this model provides a realistic gradual worsening of asthma, under well-controlled laboratory conditions. Importantly, the study also shows that these changes are well tolerated and transient, underlining the safety and ethical acceptability of this investigational model.

Others have recently published similar results in abstract form. In these studies low-dose allergen exposure produced variable airways obstruction [27], elevated serum ECP [28], and an increased IL-4 to interferon (IFN)- $\gamma$ ratio in stimulated peripheral blood mononuclear cells $e x$ vivo [29]. However, at present it is unknown whether this is accompanied by features of chronic airways inflammation, which could eventually lead to structural airways remodelling.

\section{A model of chronic airways inflammation?}

In experimental animals some major features of chronic airways inflammation have been established following repeated low-dose allergen exposure. These studies have demonstrated the induction of (apart from leucocyte infiltration): airways hyperresponsiveness to cholinergic agonists [30, 31], but not to allergen [30]; an increase in smooth muscle shortening capacity [32]; smooth muscle 
growth [33-36]; epithelial damage [35] and proliferation [34]; subepithelial collagen type III and VI deposition [31]; goblet cell proliferation [31, 36]; sub-mucosal gland hypertrophy and hyperplasia [35]; and impaired nitric oxide production [37].

The development of such changes in response to repeated allergen exposure has not yet been confirmed in asthmatics, even though single-dose allergen challenge has been reported to increase the number of myofibroblasts in bronchial biopsy specimens [38]. It can be envisaged that well-controlled repeated low-dose allergen exposure is a promising approach to investigate the cellular and molecular pathways for the development of airways remodelling $[15,39]$. Then it may be possible to describe not only the presence of growth factors, such as transforming growth factor (TGF)- $\beta$, within the airways in asthma [40, 41], but also to investigate the dynamics of these factors and their consequences, as induced by allergen, in more detail [42]. If the induced changes appear to be reversible, as appears from the study by SulaKvelidze et al. [26], then there do not seem to be major ethical restrictions to this kind of research.

\section{Perspectives}

lt can be envisaged that human laboratory allergen challenges will evolve towards more realistic research models of environmental allergen exposure in asthma. This will certainly allow progress in the research on the pathogenesis of acute as well as chronic airways inflammation in asthma. Interestingly, the repeated low-dose allergen model might be applicable to the careful investigation, in the laboratory setting, of the interaction between multiple environmental exposures in asthma, for instance between allergens and photochemical air pollution [43] or the occurrence of a respiratory virus infection on top of seasonal chronic allergen exposure [44]. Needless to say, the combination of challenges with low-dose allergen [26] with air pollutants [45] or experimental virus infection [14] also has prospects for well-controlled intervention studies with newly developed drugs.

\section{References}

1. National Heart, Lung, and Blood Institute, National Institutes of Health Bethesda, Maryland. International consensus report on diagnosis and treatment of asthma. Eur Respir J 1992; 5: 601-641.

2. Wilkinson J, Holgate ST. Candidate gene loci in asthmatic and allergic inflammation. Thorax 1996; 51: 3-8.

3. Postma DS, Bleecker ER, Amelung PJ, Holroyd KJ, Xu J, Panhuysen CIM, Meyers DA, Levitt RC. Genetic susceptibility to asthma. Bronchial hyperresponsiveness coinherited with a major gene for atopy. $N$ Engl J Med 1995; 333: 894-900.

4. Sporik R, Holgate ST, Platts-Mills TAE, Cogswell JJ. Exposure to house-dust mite allergen (Der p l) and the development of asthma in childhood. A prospective study. N Engl J Med 1990; 323: 502-507.

5. Arshad SH, Matthews S, Gant C, Hide DW. Effect of allergen avoidance on development of allergic disorders in infancy. Lancet 1992; 339: 1493-1497.
6. Welliver RC. RSV and chronic asthma. Lancet 1995; 34: 789-790.

7. Corne JM, Holgate ST. Mechanisms of virus induced exacerbations of asthma. Thorax 1997; 52: 380-389.

8. Djukanovic R, Roche WR, Wilson JW, et al. Mucosal inflammation in asthma. Am Rev Respir Dis 1990; 142: 434-457.

9. Sont JK, van Krieken JHJM, Evertse ChE, Hooijer R, Willems LNA, Sterk PJ. Relationship between the inflammatory infiltrate in bronchial biopsy specimens and clinical severity of asthma in patients treated with inhaled steroids. Thorax 1996; 51: 496-502.

10. Humbert M, Corrigan ChJ, Kimmitt P, Till SJ, Kay AB, Durham SR. Relationship between IL-4 and IL-5 mRNA expression and disease severity in atopic asthma. Am J Respir Crit Care Med 1997; 156: 704-708.

11. Bentley AM, Meng Q, Robinson DS, Hamid Q, Kay AB, Durham SR. Increases in activated T lymphocytes, eosinophils, and cytokine mRNA expression for interleukin-5 and granulocyte/macrophage colony-stimulating factor in bronchial biopsies after allergen inhalation challenge in atopic asthmatics. Am J Respir Cell Mol Biol 1993; 8: 34-42,

12. Diamant Z, Timmers MC, van der Veen $\mathrm{H}$, et al. The effect of MK-0591, a novel 5-lipaxygenase activating protein (FLAP) inhibitor, on leukotriene biosynthesis and allergen-induced airway responses in asthmatic subjects in vivo. J Allergy Clin Immunol 1995; 95: 42-51.

13. Grünberg K, Timmers MC, Smits HH, et al. Effect of experimental rhinovirus 16 colds on airway hyperresponsiveness and interleukin- 8 in nasal lavage in asthmatic subjects in vivo. Clin Exp Allergy 1997; 27: 36-45.

14. Grünberg K, Smits HH, Timmers MC, et al. Experimental rhinovirus 16 infection. Effects on cell differentials and soluble markers in sputum in asthmatic subjects. Am J Respir Crit Care Med 1997; 156: 606-616.

15. Paré PD, Bai TR. The consequences of chronic allergic inflammation. Thorax 1995; 50: 328-332.

16. Boulet L-Ph, Laviolette $\mathrm{M}$, Turcotte $\mathrm{H}$, et al. Bronchial subepithelial fibrosis correlates with airway responsiveness to methacholine. Chest 1997; 112: 45-52.

17. Lambert RK, Wiggs BR, Kuwano K, Hogg JC, Pare PD. Functional significance of increased airway smooth muscle in asthma and COPD. J Appl Physiol 1993; 74: 27712781.

18. Li X, Wilson JW. Increased vascularity of the bronchial mucosa in mild asthma. Am J Respir Crit Care Med 1997; 156: 229-233.

19. Boulet L-Ph, Belanger M, Carrier G. Airway responsiveness and bronchial-wall thickness in asthma with or without fixed airflow obstruction. Am J Respir Crit Care Med 1995; 152: 865-871.

20. Bai TR, Cooper T, Weir R, Wiggs B, Koelmeyer R. Airway wall thickening is greater in middle-aged compared with young adults with fatal asthma. Am J Respir Crit Care Med 1997; 155(4, part 2): A503.

21. Macklem PT. A theoretical analysis of the effect of airway smooth muscle load on airway narrowing. Am J Respir Crit Care Med 1996; 153: 83-89.

22. Cockcroft DW, Ruffin RE, Hargreave FE. Appearance of allergen-induced increases in airway responsiveness only after repeated allergen inhalations in two subjects. Clin Exp Allergy 1989; 19: 225-227.

23. Coyle AJ, Erard F, Bertrand C, Walti S, Pircher H, Le Gros G. Virus specific CD8+ cells can switch to interleukin 5 production and induce airway eosinophilia. $J$ Exp Med 1995; 181: 1229-1233. 
24. Bianco A, Sethi SK, Prior C, Knight R, Spiteri MA. Th2 cytokines, IL-4, IL 5, IL-13 upregulate ICAM-1 expression in rhinoviral-infected airway epithelial cells. Eur Respir J 1997; 10 (Suppl. 25): 125s.

25. Ihre E, Zetterstrom O. Increase in non specific bronchial responsiveness after repeated inhalation of low doses of allergen. Clin Exp Allergy 1993; 23: 298-305.

26. Sulakvelidze I, Inman MD, Rerecich T, O'Byrne PM. Increases in airway eosinophils and interleukin-5 with minimal bronchoconstriction during repeated low-dose allergen challenge in atopic asthmatics. Eur Respir $J$ 1998; 11: 821-827.

27. Palmqvist M, Pettersson K, Sjöstrand M, Löwhagen O, Lötvall J. Variability of lung function during repeated low dose blinded allergen exposure in mild asthmatics. Am J Respir Crit Care Med 1997; 155 (4, part 2): A883.

28. Krieger P, de Blay F, Spirlet F, Demangeat C, Duvernel C, Kassel O, Pauli G, Frossard N. Allergen-induced inflammation in bronchoalveolar lavage and in serum: ECP levels after repeated inhalation of low doses of allergen Fel d 1. Eur Respir J 1997; 10: Suppl. 25, 292s.

29. Gabrielsson S, Pauli S, Roquet A, et al. Increased allergen-specific Th2 responses in vitro in atopic subjects receiving subclinical allergen challenge. Allergy 1997; 52: $860-865$.

30. Cui Z-H, Pullerits T, Lindén A, Skoogh B-E, Lötvall J. Repeated low dose allergen challenge increases acetylcholine responsiveness but attenuates high dose allergen response in guinea pigs. Eur Respir J 1997; 10: Suppl. 25, 476s.

31. Palmans E, Kips JC, Pauwels RA. Allergen induced structural airways changes in an in vivo rat model. Eur Respir J 1997; 10: Suppl. 25, 475s.

32. Ishida K, Pare PD, Thomson RJ, Schellenberg RR. Increased in vitro responses of tracheal smooth muscle from hyperresponsive guinea pigs. J Appl Physiol 1990; 68: 1316-1320.

33. Wang CG, Du T, Xu LJ, Martin JG. Role of leukotriene D4 in allergen-induced increases in airway smooth muscle in the rat. Am Rev Respir Dis 1993; 148: 413-417.

34. Wang ZL, Walker BARM, Weir TD, et al. Effects of chronic antigen and beta-2 agonist exposure on airway remodeling in guinea pigs. Am J Respir Crit Care Med 1995; 152: 2097-2104.

35. Padrid Ph, Shook S, Finucane Th, et al. Persistent airway hyperresponsiveness and histologic alterations after chronic antigen challenge in cats. Am J Respir Crit Care Med 1995; 151: 184-193.

36. Kips JC, Palmans E, Pauwels RA. Repeated antigen exposure leads to structural airway changes in rats. Am J Respir Crit Care Med 1997; 155 (4, part 2): A546.

37. Mehta S, Lilly CM, Rollenhagen JE, Haley KJ, Asano K, Drazen JM. Acute and chronic effects of allergic airway inflammation on pulmonary nitric oxide production. Am J Physiol 1997; 272: L124-L131.

38. Gizycki MJ, Rogers AV, Adelroth E, O'Byrne PM. Ultrastructure of allergen-induced myofibroblasts in asthma. Am J Respir Crit Care Med 1997; 155 (4, part 2): A371.

39. Redington AK, Howarth PH. Airway wall remodelling in asthma. Thorax 1997; 52: 310-312.

40. Vignola AM, Chanez R, Chiappara G, et al. Transforming growth factor- $\beta$ expression in mucosal biopsies in asthma and chronic bronchitis. Am J Respir Crit Care Med 1997; 156: 591-599.

41. Minshall EM, Leung DYM, Martin RJ, et al. Eosinophil-associated TGF- $\beta 1$ mRNA expression and airway fibrosis in bronchial asthma. Am J Respir Cell Mol Biol 1997; 17: 326-333.

42. Redington AK, Madden J, Frew AJ, et al. Transforming growth factor- $\beta 1$ in asthma. Measurement in bronchoalveolar lavage fluid. Am J Respir Crit Care Med 1997; 156: 642-647.

43. Hiltermann TJN, Bruijne CR, Stolk J, et al. Effects of photochemical air pollution and allergen exposure on upper respiratory tract inflammation in asthmatics. Am J Respir Crit Care Med 1997; 156: 1765-1772.

44. Johnston SL, Pattemore PK, Sandeson G, et al. The relationship between upper respiratory infections and hospital admissions for asthma: a time trend analysis. Am J Respir Crit Care Med 1996; 154: 654-660.

45. Hiltermann TJN, Stolk J, Hiemstra PS, et al. Effect of ozone exposure on maximal airway narrowing in non-asthmatic and asthmatic subjects. Clin Sci 1995; 89: 619-624. 